\title{
FAKTOR-FAKTOR YANG MEMENGARUHI KEPUTUSAN PEMBELIAN KONSUMEN GENERASI Z DI RESTORAN WILAYAH KELAPA GADING
}

\section{FACTORS AFFECTING CONSUMER PURCHASE DECISION FOR GENERATION Z IN KELAPA GADING RESTAURANTS}

\author{
Jimmy Muller Hasoloan Situmorang ${ }^{1)^{*}}$, Regine Novania ${ }^{2)}$, Christel Natalia ${ }^{3)}$ \\ ${ }^{1)}$ Fakultas Pariwisata - Universitas Pelita Harapan \\ ${ }^{2}$ Fakultas Pariwisata - Universitas Pelita Harapan \\ ${ }^{3)}$ Fakultas Pariwisata - Universitas Pelita Harapan
}

Diterima 20 Mei 2021 /Disetujui 28 Mei 2021

\begin{abstract}
The number of food and beverage industry and the development of its technology has grown very rapid annually, thus made the eating and drinking out activities become a new lifestyle. Generation $Z$ is known as the generation that likes practicality, for example, they prefer to buy food from restaurants rather than preparing and cooking it at home. Consequently, this study will reveal factors that influence the purchase decision of generation $Z$ consumers in restaurants at Kelapa Gading district. The decision to choose Kelapa Gading district because it has the most restaurants amongst all the North Jakarta districts. The data used are the results of a survey from a questionnaire made with a Likert scale. This research is a quantitative research and uses inferential statistics to analyze the relationship between the six factors that affecting purchase decision for generation $Z$ consumers, which are customer service, availability of variety and junk food, maintenance of privacy, brand name, availability of ready-made food, and health protokol. Of the six factors studied, there are three factors that have significant influence on the purchase decision of generation $Z$ consumers in restaurants at Kelapa Gading district, which were availability of variety and junk food, brand name, and availability of ready-made food, while the other three factors do not have significant influence regarding the purchase decision.
\end{abstract}

Keywords: inferential statistics, generation Z, purchase decisions, restaurants

\section{ABSTRAK}

Meningkatnya jumlah usaha makanan dan minuman serta berkembangnya teknologi dengan sangat pesat setiap tahunnya, membuat aktivitas untuk makan dan minum di luar rumah menjadi sebuah gaya hidup yang baru. Generasi $\mathrm{Z}$ dikenal dengan generasi yang menyukai hal yang praktis, contohnya mereka lebih memilih untuk membeli makanan dari restoran daripada menyiapkan dan memasak makanan di rumah. Oleh karena itu, penelitian ini dilakukan untuk mencari tahu faktor-faktor apa saja yang memengaruhi keputusan pembelian konsumen generasi Z di restoran wilayah Kelapa Gading. Kecamatan Kelapa Gading dipilih karena daerah tersebut memiliki jumlah restoran paling banyak dibandingkan dengan kecamatan yang berada di Jakarta Utara. Data yang digunakan merupakan hasil survey dari kuisioner yang dibuat dengan skala Likert. Penelitian ini merupakan penelitian kuantitatif dan menggunakan statistik inferensial untuk menganalisis hubungan faktorfaktor yang digunakan dengan keputusan pembelian konsumen generasi $Z$. Terdapat enam faktor yang diteliti yaitu layanan pelanggan, ketersediaan variasi makanan, pemeliharaan privasi, nama merek, ketersediaan makanan cepat saji, dan protokol kesehatan. Hasil yang didapatkan adalah hanya tiga faktor yang memiliki pengaruh yang signifikan terhadap keputusan pembelian generasi $Z$ yaitu ketersediaan variasi makanan, nama merek, dan ketersediaan makanan cepat saji, sedangkan tiga faktor lainnya tidak memiliki pengaruh yang signifikan.

Kata Kunci: statistik inferensial, generasi Z, keputusan pembelian, restoran

Industri makanan dan minuman merupakan bagian dari industri perhotelan yang merupakan salah satu penggerak perekonomian Indonesia. Menurut 
Kementerian Perindustrian, kontribusi industri makanan dan minuman terhadap Produk Domestik Bruto (PDB) terus meningkat (Mahardika, 2018). Oleh karena itu, industri makanan dan minuman berperan penting dalam perekonomian negara. Menurut SK Menteri Pariwisata dan Komunikasi no. KM73.PW 105/MPPT-85, restoran diartikan sebagai suatu bentuk usaha pangan yang berada dalam sebuah bangunan dimana didalamnya terdapat berbagai peralatan dan perlengkapan untuk proses pengolahan, penyajian, dan penjualan makanan dan minuman (Aditama, 2011). Hal ini membuat usaha restoran menjadi usaha yang menjanjikan karena menyangkut kebutuhan utama manusia, yaitu makanan dan minuman.

Pertumbuhan restoran di Jakarta terus mengalami peningkatan, salah satunya di wilayah Jakarta Utara. Kelapa Gading merupakan salah satu kecamatan yang memiliki jumlah restoran terbanyak dibandingkan dengan wilayah kecamatan lainnya yang berada di Jakarta Utara. Seiring dengan perkembangan zaman, teknologi juga semakin maju dan membuat gaya hidup manusia berubah. Sehingga banyak orang yang memilih untuk pergi makan ke restoran dibandingkan makan di rumah. Menurut data yang didapatkan dari Tribunnews.com mencatat sepanjang tahun 2013, orang Indonesia yang mengunjungi restoran mencapai 308 juta kali dan pencarian restoran secara daring mencapai 40 juta kali (Abdullah, 2017).

Generasi Z lahir dan tumbuh pada saat teknologi digital berkembang dengan cepat, sehingga teknologi informasi sudah menjadi bagian dari kehidupan sehari-hari (Irwanto \& Hariatiningsih, 2019).

Dengan adanya media sosial, promosi lebih mudah untuk diakses oleh kalangan muda karena mampu menjadi pendongkrak eksistensi tertinggi dalam sebuah usaha restoran. Selain itu dengan adanya rekomendasi dari food blogger maupun rekomendasi banyak orang di media sosial dinilai mampu memengaruhi niat dalam melakukan keputusan pembelian di restoran (Syahbani \& Widodo, 2017). Lebih lanjut, aktivitas makan dan minum bagi generasi $\mathrm{Z}$ tidak hanya sekadar pemenuhan kebutuhan biologis saja, tetapi lebih kompleks bila dilihat dari aspek konsep, seperti aspek menu, lanskap interior-eksterior, proses penyajian dan pelayanannya, serta harga promosi yang ditawarkan. Bagi generasi ini, aktivitas tersebut sudah menjadi urusan sosial. (Irwanto \& Hariatiningsih, 2019).

Namun pada tahun 2020, orang-orang menjadi tidak bebas untuk makan di restoran karena adanya wabah COVID-19. Untuk menekan jumlah korban yang terinfeksi COVID-19, maka pemerintah Indonesia menerapkan PSBB (Pembatasan Sosial Berskala Besar) dimana masyarakat harus menghindari kerumunan atau tempat-tempat yang ramai. Selain itu juga, Menteri

Kesehatan Republik Indonesia telah mengeluarkan surat edaran dengan nomor HK.01.07/MENKES/382/2020 tentang Protokol Kesehatan bagi masyarakat di tempat dan fasilitas umum dalam rangka pencegahan dan pengendalian COVID-19, yang harus diikuti oleh restoran untuk menerapkan protokol kesehatan bagi konsumen yang datang (Kemenkes, 2020).

Disebutkan bahwa ada lima faktor yang memengaruhi konsumen dalam memilih restoran, yaitu customer service, availability of variety and junk food, maintenance of privacy, brand name, dan availability of ready-made food. Hasil dari penelitian ini membuktikan bahwa makan diluar rumah menjadi gaya masa kini di kota Dhaka, Bangladesh karena terjadinya peningkatan pendapatan masyarakatnya. Kemudian selanjutnya, konsumen di kota Dhaka, Bangladesh lebih memperhatikan faktor customer service, maintenance of privacy, brand name dan availability of ready-made food didalam memilih restoran. Sedangkan faktor availability of variety and junk food tidak dianggap mempunyai pengaruh signifikan oleh konsumen. (Islam, N. et al., 2018). Penelitian lainnya ialah tentang faktorfaktor yang menentukan pilihan konsumen untuk tempat makan bagi masyarakat Surabaya. Hasil yang didapat dari penelitian ini ialah selama dua tahun terakhir, perkembangan bisnis industri makanan di Surabaya bertumbuh sangat pesat. Terdapat empat faktor yang memengaruhi konsumen dalam memilih restoran yaitu service delivery, servicescape, product dan technology (Tungkiman, 2016). Penelitian berikutnya tentang faktor pertimbangan generasi $\mathrm{Z}$ dalam memilih restoran di kota Bandung menyebutkan bahwa terdapat tujuh faktor pertimbangan dalam pemilihan restoran berdasarkan persepsi generasi $\mathrm{Z}$ yaitu, faktor 
suasana, kualitas produk dan harga, tempat dan fasilitas, kualitas pelayanan, trustworthiness, branding dan promosi (Asmara, 2020). Banyaknya usaha restoran yang terus bertumbuh dan berkembang menyebabkan faktor-faktor yang memengaruhi keputusan pembelian konsumennya menjadi sebuah hal yang perlu dicermati (Ghanimata, 2012). Restoran yang tetap beroperasi haruslah mempunyai Protokol Kesehatan yang harus dipenuhi (Nirwaty \& Agave, 2020). Dengan berdasarkan uraian hal diatas, peneliti tertarik untuk melakukan penelitan dengan judul "Faktor-faktor yang memengaruhi keputusan pembelian konsumen generasi $\mathrm{Z}$ di restoran wilayah Kelapa Gading”. Rumusan masalahnya adalah (a) apakah customer service berpengaruh terhadap keputusan pembelian konsumen generasi $\mathrm{Z}$ di restoran wilayah Kelapa Gading? (b) apakah availability of variety and junk food berpengaruh terhadap keputusan pembelian konsumen generasi $\mathrm{Z}$ di restoran wilayah Kelapa Gading? (c) apakah maintenance of privacy berpengaruh terhadap keputusan pembelian generasi $\mathrm{Z}$ di restoran wilayah Kelapa Gading? (d) Apakah brand name berpengaruh terhadap keputusan pembelian konsumen generasi $\mathrm{Z}$ di restoran wilayah Kelapa Gading? (e) apakah availability of ready-made food berpengaruh terhadap keputusan pembelian konsumen generasi $\mathrm{Z}$ di restoran wilayah Kelapa Gading? (f) apakah protokol Kesehatan berpengaruh terhadap keputusan pembelian konsumen generasi $\mathrm{Z}$ di restoran wilayah Kelapa Gading?

Penelitian ini dapat bermanfaat bagi pihak restoran dan sektor industri makanan dan minuman agar dapat mempertimbangkan faktor-faktor apa saja yang memengaruhi keputusan pembelian konsumen generasi $\mathrm{Z}$ di restoran yang dikunjungi. Generasi $\mathrm{Z}$ digaungkan sebagai konsumen potensial masa depan sehingga hal ini memunculkan pertanyaan bagaimana pandangan generasi $\mathrm{Z}$ terhadap suatu restoran yang diinginkan (Asmara, 2020). Diharapkan, faktor-faktor tersebut dapat digunakan sebagai strategi dalam menumbuhkan dan mengembangkan bisnis makanan dan minuman, terutama dalam era normal baru.

Keputusan Pembelian

Keputusan pembelian merupakan suatu keputusan yang dilakukan karena memiliki ketertarikan yang didasarkan oleh seseorang terhadap suatu produk dan ingin membeli, mencoba, menggunakan atau memiliki produk tersebut (Marlinus, 2017). Proses keputusan pembelian digunakan perusahaan perhotelan dan pariwisata untuk lebih memahami perilaku pembelian pelanggan mereka secara lebih akurat. Menurut Kotler dan Amstrong, perilaku pembelian konsumen ini adalah merupakan perilaku pembelian konsumen pada saat akhir, baik perorangan maupun rumah tangga, yang membeli barang dan jasa untuk konsumsi pribadi (Astika et al., 2017). Menurut Basu Swata, keputusan dalam pembelian mengidentifikasikan semua pilihan yang memiliki kemungkinan untuk memecahkan persoalan dan menilai pilihan secara sistematis dan obyektif serta sasaran yang menentukan kerugian masing-masing (Gariswasita, 2013). Oleh karena itu, sebelum konsumen memiliki keputusan untuk memilih sebuah barang atau jasa yang akan dibeli nantinya, konsumen akan mengidentifikasikannya terlebih dahulu. Proses mengidentifikasi tersebut bertujuan untuk mengevaluasi apakah barang atau jasa tersebut sesuai dengan apa yang sedang dibutuhkan atau tidak. Setelah dilakukan proses identifikasi, maka konsumen akan melakukan pembelian produk atau jasa yang sesuai dengan kebutuhan atau keinginan konsumen.

Faktor Customer Service

Pelayanan dalam industri restoran memiliki pengaruh yang signifikan terhadap kepuasan konsumen. Konsumen biasanya menilai kualitas restoran dari kualitas makanan, lingkungan, dan pelayanan yang diberikan oleh karyawan. Menurut Han dan Ryu, kepuasan pelanggan dapat diperoleh dengan adanya pelayanan yang berkualitas dari restoran. Dengan demikian, hal tersebut dapat membuat restoran mendapatkan keuntungan yang lebih besar (Lee \& Kim, 2012). Menurut Winarsih, pelayanan itu sendiri diartikan sebagai suatu kegiatan yang tidak dapat dilihat maupun diraba dan terjadi karena adanya interaksi antara karyawan dengan pelanggan untuk menyelesaikan permasalahan pelanggan. Kotler dan Keller juga menyatakan bahwa kepuasan konsumen akan muncul sebagai rasa senang atau kecewa setelah membandingkan hasil dari produk yang didapatkan dengan yang diharapkan (Akbar, 2016). Oleh karena itu, semakin baik tingkat kualitas pelayanan yang diberikan 
maka konsumen akan merasa lebih puas (Krisdianti \& Sunarti, 2019).

Faktor Availability of variety and Junk Food

Ketersediaan variasi makanan menjadi salah satu daya tarik bagi restoran untuk dikunjungi oleh konsumen. Dengan adanya berbagai variasi makanan dalam restoran, maka konsumen akan lebih tertarik untuk memesan makanan yang ada di restoran daripada yang disajikan di rumah (Kusumawaty, 2012). Selain variasi makanan, kualitas makanan juga perlu diperhatikan., Peri juga mengatakan bahwa untuk memenuhi kebutuhan dan mencapai kepuasan pelanggan, restoran perlu menggunakan bahan-bahan makanan yang berkualitas dalam mengelola makanan. Karakteristik dari sebuah makanan yang berkualitas dapat dilihat dari penyajian makanan tersebut, rasa, variasi makanan yang disajikan dan variasi makanan sehat, serta kesegaran dan temperatur makanan tersebut (Hanaysha, 2016). Makanan cepat saji diartikan sebagai makanan yang berkalori tinggi, berkadar gula dan garam yang tinggi, rendah vitamin dan nutrisi serta dapat meningkatkan resiko penyakit seperti obesitas, diabetes, penyakit jantung, dan hipertensi (Mirhadyan et al., 2019). Namun, menurut Medinna Kabir Tamanna, penelitian yang dilakukan pada kaum konsumen muda cenderung lebih memilih untuk makan di restoran cepat saji karena memiliki harga makanan yang terjangkau, kualitas pelayanan, dan suasana yang nyaman (Islam, N. et al., 2018).

\section{Faktor Maintenance of Privacy}

Lokasi restoran merupakan faktor penting dalam menentukan ramai atau sepinya pengunjung karena dapat memengaruhi kenyamanan konsumen (Rachmawati, 2011). Restoran yang ramai biasanya akan mengundang konsumen untuk datang karena memberikan kesan yang seru dan memperlihatkan popularitas restoran. Namun, terkadang antrian restoran yang panjang dengan keadaan restoran yang penuh dapat menyulitkan pelanggan juga saat masuk ke restoran (Hwang et al., 2011). Selain itu, dalam situasi yang ramai, hal-hal yang tidak diinginkan dapat terjadi dan dapat mengganggu kenyamanan dan privasi pelanggan.

\section{Faktor Brand Name}

Menurut Churchill (2005), merek merupakan suatu nama, tanda, simbol, atau desain yang digunakan untuk menunjukkan kepemilikan serta membedakan produk yang dijual oleh suatu perusahaan dengan perusahaan lainnya. Neupane (2015) menyatakan bahwa citra suatu brand memiliki hubungan erat dengan kepuasan konsumen dan kesetiaan konsumen. Citra brand yang baik mampu meningkatkan kepuasan konsumen dan kesetiaan konsumen (Waluya \& Iqbal, 2019). Menurut Tepeci (1999), jika konsumen sudah mendapatkan pengalaman baik dengan suatu brand, maka konsumen tersebut akan setia kepada brand tersebut dan mempromosikan merek tersebut kepada orang lain. Zeithaml (1998) menyatakan bahwa harga merupakan sesuatu yang dikorbankan untuk mendapat produk yang diinginkan. Dengan adanya kewajaran harga produk yang ditawarkan, maka perusahaan akan mampu menaikkan citra merek dan meningkatkan kepuasan konsumen (Jin et al., 2012).

\section{Faktor Availability of Ready-made Food}

Restoran yang menyediakan makanan cepat saji merupakan restoran yang menyajikan makanan yang dipesan konsumen dengan cepat (Mandasari \& Tama, 2011). Menurut Traub dan Odland (1979), convenience food atau makanan cepat saji tidak hanya menghemat waktu dalam memasak, tapi juga tidak membutuhkan energi dan keterampilan masak yang tinggi, karena sebagian dari proses memasak sudah dilakukan oleh pengolah makanan (Olsen et al., 2012). Kategori ready-made food dapat diartikan dalam beberapa pengertian. Mulai dari ready to heat meals, dimana konsumen hanya perlu menghangatkan makanan tersebut dengan hanya menggunakan microwave, hingga makanan untuk anak-anak yang perlu dimasak dari bahan-bahan yang sudah disiapkan dalam kemasan (Wheeler, 2017). Bugge, Lillebo, \& Lavik (2018) mengatakan bahwa penelitian menemukan banyak konsumen yang bergantung pada makanan cepat saji, selain itu banyak juga wanita muda yang membuat permintaan akan makanan sehat siap saji (Olsen et al., 2012).

Faktor Protokol Kesehatan

Kasus COVID-19 pertama kali dilaporkan di Indonesia pada tanggal 2 Maret 2020 dan untuk menangani kasus ini, pemerintah 
mengeluarkan beberapa aturan untuk mengisolasi diri di rumah dan tidak melakukan aktivitas di luar rumah. Hal ini sangat berdampak pada bisnis restoran karena mengakibatkan turunnya jumlah konsumen. Tetapi beberapa dari konsumen tetap memesan makanan dari restoran untuk memenuhi kebutuhannya. Oleh karena itu selama pandemi COVID-19, restoran diwajibkan untuk memiliki prosedur khusus yang harus dijalankan secara konsisten agar konsumen dapat merasa nyaman dan aman saat mengonsumsi makanan dari restoran tersebut (Nirwaty \& Agave, 2020). Menurut Tirto.id perilaku disiplin untuk menerapkan perilaku 3M (Memakai masker, Mencuci tangan dan Menjaga jarak) sangat penting untuk menekan adanya virus COVID-19.

Restoran

Arief (2005:31) menyatakan bahwa restoran adalah suatu industri yang tak terbatas, yaitu industri yang melayani makanan dan minuman kepada semua orang yang jauh dari rumahnya, maupun yang dekat dari rumahnya (Wahyuningsih, 2019). Menurut Peraturan Kementerian Pariwisata dan Ekonomi Kreatif No.11 Tahun 2014, restoran adalah usaha penyediaan jasa makanan dan minuman dilengkapi dengan peralatan dan perlengkapan untuk proses pembuatan, penyimpanan dan penyajian di suatu tempat tetap yang tidak berpindah-pindah dengan tujuan memperoleh keuntungan atau laba. Selain menyediakan jasa makanan dan minuman, restoran juga memiliki tujuan untuk dapat memperoleh keuntungan atau laba bagi pemilik restoran tersebut. Menurut Masrum Widjojo Admojo dalam buku restoran dan segala permasalahannya (2007) memiliki sebelas tipe restoran secara umum, yaitu table d'hote restaurant, coffee shop, dining room, pizzeria, speciality, dan familly type restaurant yang merupakan restoran untuk tamu rombongan. Selain itu terdapat $a$ la carte restaurant, dimana restoran menyediakan berbagai pilihan menu individual yang dapat dipilih oleh konsumen dan snack bar yang merupakan sebuah restoran dengan tempat yang kecil namun memiliki pelayanan yang cepat (Sumarsono, 2015 hal 21-22).

\section{Generasi Z}

Generasi $Z$ atau generasi pascamilenial adalah kelompok manusia termuda di dunia saat ini. Kelahiran generasi Z terjadi pada tahun 1995 hingga 2010 (Agustina, 2018). Generasi Z mempunyai sifat gabungan antara aspek fisik dan digital, artinya segala aspek dunia maya dan dunia nyata saling menyatu (Irwanto \& Hariatiningsih, 2019). Menurut Prayekti (2019) Generasi Z juga memiliki karakter yang menyukai kemudahan, kepraktisan dan kecepatan dalam proses transaksi. Generasi Z cenderung suka bereksperimen dan mencoba sesuatu yang baru, serta generasi ini lebih mudah terganggu fokusnya terhadap hal-hal yang baru (Asmara, 2020). Oleh karena itu, golongan generasi $\mathrm{Z}$ lebih banyak menyukai hal yang praktis dan cepat contohnya dengan membeli makanan dari restoran, mereka tidak perlu menyiapkan dan membereskan makanan yang akan mereka nikmati.

\section{Gambar 1. Rerangka Konseptual}

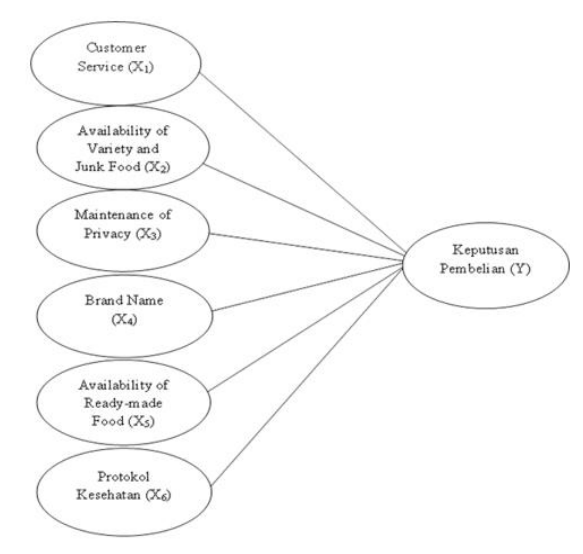

Sumber: Hasil Olahan Data (2020)

Berdasarkan rerangka konseptual diatas, maka hipotesis dalam penelitian ini adalah:

1. $\mathrm{H}_{1}$ : Customer service berpengaruh signifikan terhadap keputusan pembelian konsumen generasi $\mathrm{Z}$ di restoran wilayah Kelapa Gading.

$\mathrm{H}_{0}$ : Customer service tidak berpengaruh signifikan terhadap keputusan pembelian konsumen generasi $\mathrm{Z}$ di restoran wilayah Kelapa Gading.

2. $\mathrm{H}_{2}$ : Availability of variety and junk food berpengaruh signifikan terhadap keputusan pembelian konsumen generasi $\mathrm{Z}$ di restoran wilayah Kelapa Gading.

$\mathrm{H}_{0}$ : Availability of variety and junk food tidak berpengaruh signifikan terhadap keputusan pembelian konsumen generasi $\mathrm{Z}$ di restoran wilayah Kelapa Gading.

3. $\mathrm{H}_{3}$ : Maintenance of privacy berpengaruh signifikan terhadap keputusan pembelian 
konsumen generasi $\mathrm{Z}$ di restoran wilayah Kelapa Gading.

$\mathrm{H}_{0}$ : Maintenance of privacy tidak berpengaruh signifikan terhadap keputusan pembelian konsumen generasi $\mathrm{Z}$ di restoran wilayah Kelapa Gading.

4. $\mathrm{H}_{4}$ : Brand name berpengaruh signifikan terhadap keputusan pembelian konsumen generasi $\mathrm{Z}$ di restoran wilayah Kelapa Gading.

$\mathrm{H}_{0}$ : Brand name tidak berpengaruh signifikan terhadap keputusan pembelian konsumen generasi $\mathrm{Z}$ di restoran wilayah Kelapa Gading.

5. $\mathrm{H}_{5}$ : Availability of ready-made Food berpengaruh signifikan terhadap keputusan pembelian konsumen generasi $\mathrm{Z}$ di restoran wilayah Kelapa Gading.

$\mathrm{H}_{0}$ : Availability of ready-made Food tidak berpengaruh signifikan terhadap keputusan pembelian konsumen generasi $\mathrm{Z}$ di restoran wilayah Kelapa Gading.

6. $\mathrm{H}_{6}$ : Protokol kesehatan berpengaruh signifikan terhadap keputusan pembelian konsumen generasi $\mathrm{Z}$ di restoran wilayah Kelapa Gading.

$\mathrm{H}_{0}$ : Protokol kesehatan tidak berpengaruh signifikan terhadap keputusan pembelian konsumen generasi $\mathrm{Z}$ di restoran wilayah Kelapa Gading.

\section{Metode Penelitian}

Penelitian ini termasuk ke dalam penelitian kuantitatif dan statistik inferensial dimana statistik inferensial digunakan untuk menganalisis hasil data yang diperoleh dari sampel dan kemudian data tersebut diberlakukan sebagai suatu simpulan bagi populasi (Sugiyono, 2017, hal. 148). Metode pengumpulan data yang dilakukan juga menggunakan metode kuisioner yang dilakukan secara daring. Target responden yang diambil adalah konsumen generasi $\mathrm{Z}$ yang pernah datang dan makan di restoran wilayah Kelapa Gading. Penentuan responden yang digunakan adalah metode probability sampling dan nonprobability sampling dengan metode convenience sampling. Menurut Hair et al. 1995 pengukuran sampel yang representative adalah jumlah indikator yang digunakan pada semua variabel dikalikan 5-10 (Fitriatun, 2019). Pada penelitian ini terdapat 20 indikator sehingga pada penelitian ini sampel yang digunakan yaitu lima kali jumlah indikator variabel yang digunakan. Sehingga batas minimal responden penelitian ini adalah 100 . Kuesioner dengan jumlah 20 indikator pada seluruh variabel disusun dengan menggunakan skala Likert yang menggunakan skala 5 poin untuk mengukur seberapa tinggi subjek yang setuju dan tidak setuju. Pengukurannya yaitu $1=$ sangat tidak setuju, $2=$ tidak setuju, $3=$ netral, $4=$ setuju, 5 = sangat setuju. Data yang digabungkan kemudian diolah dengan menggunakan alat bantu analisis statistik lunak smartPLS (Partial Least Square) dengan menggunakan pendekatan SEM (Structural Equation Modeling Least).

\section{Hasil dan Pembahasan}

Tabel 1 menunjukkan dari total responden yang telah berpartisipasi berjumlah 126 responden. Karena penelitian ini dilakukan pada konsumen generasi $\mathrm{Z}$, maka responden yang mengisi kuisioner ini adalah orang yang berumur antara 15 sampai 25 tahun. Mayoritas responden yang mengisi kuisioner ini memiliki rentang usia $19-22$ tahun dengan frekuensi 102 orang (81\%), diikuti dengan yang berusia $22-25$ tahun dengan frekuensi 32 orang $(18,3 \%)$ dan untuk yang umur $15-18$ tahun memiliki frekuensi 1 orang $(0,8 \%)$. Untuk pendapatan perbulan, responden yang memiliki pendapatan sekitar Rp.1.000.000 - Rp.3.000.000 sebesar 62 orang (49,2\%), sedangkan untuk Rp.4.000.000 - Rp.7.000.000 sebesar 42 orang (33,3\%), untuk Rp.7.000.000 Rp.10.000.000 sebesar 10 orang $(7,9 \%)$ dan untuk yang diatas Rp.10.000.000 sebesar 12 orang $(9,5 \%)$.

Penelitian ini dilakukan untuk restoran yang berada di Kecamatan Kelapa Gading, jadi responden yang mengisi kuisioner ini adalah orang - orang yang tinggal di wilayah JaBoDeTaBek (Jakarta, Bogor, Depok,Tangerang, dan Bekasi) yang pernah makan di restoran wilayah Kelapa Gading. Responden yang tinggal di Jakarta Utara sebesar 34 orang (27\%), untuk wilayah Jakarta Timur sebesar 13 orang (10,3\%), untuk Jakarta Barat sebesar 17 orang $(13,5 \%)$, untuk Jakarta Selatan sebesar 6 orang $(4,8 \%)$, untuk Jakarta Pusat sebesar 5 orang (4\%) dan untuk BoDeTaBek sebesar 51 orang (40,5\%). Sebagian besar responden yang mengisi kuisioner ini merupakan pelajar/mahasiswa yaitu memiliki frekuensi sebesar 94 orang $(73,6 \%)$, selanjutnya terdapat pegawai swasta 
yang memiliki frekuensi sebesar 28 orang $(22,8 \%)$, wirausaha yang memiliki frekuensi sebesar 3 orang $(12,4 \%)$ dan pilot yang memiliki frekuensi sebesar 1 orang $(0,8 \%)$.

\section{Tabel 1. Data Profil Responden}

\begin{tabular}{|c|c|c|c|}
\hline & Aspek & Frekuensi & Persen \\
\hline \multirow[t]{3}{*}{ Usia } & $15-18$ tahun & 1 & $0,8 \%$ \\
\hline & $19-22$ tahun & 102 & $81 \%$ \\
\hline & $22-25$ tahun & 32 & $18,3 \%$ \\
\hline \multirow[t]{2}{*}{$\begin{array}{l}\text { Pendapatan/ } \\
\text { bulan }\end{array}$} & $\begin{array}{l}\text { Rp } 1.000 .000-R p \\
3.000 .000\end{array}$ & 62 & $49,2 \%$ \\
\hline & $\begin{array}{l}\mathrm{Rp} 4.000 .000-\mathrm{Rp} \\
7.000 .000\end{array}$ & 42 & $33,3 \%$ \\
\hline \multirow[t]{2}{*}{$\begin{array}{l}\text { Pendapatan/ } \\
\text { bulan }\end{array}$} & $\begin{array}{l}\mathrm{Rp} 7.000 .000-\mathrm{Rp} \\
10.000 .000\end{array}$ & 10 & $7,9 \%$ \\
\hline & $>$ Rp 10.000 .000 & 12 & $9,5 \%$ \\
\hline \multirow{6}{*}{$\begin{array}{l}\text { Domisili } \\
\text { tempat } \\
\text { tinggal }\end{array}$} & Jakarta Utara & 34 & $27 \%$ \\
\hline & Jakarta Timur & 13 & $10,3 \%$ \\
\hline & Jakarta Barat & 17 & $13,5 \%$ \\
\hline & Jakarta Selatan & 6 & $4,8 \%$ \\
\hline & Jakarta Pusat & 5 & $4 \%$ \\
\hline & BoDeTaBek & 51 & $40,5 \%$ \\
\hline \multirow[t]{5}{*}{ Pekerjaan } & Pelajar/mahasiswa & 94 & $74,6 \%$ \\
\hline & Pegawai swasta & 28 & $22,8 \%$ \\
\hline & Pegawai negeri & 0 & 0 \\
\hline & Wirausaha & 3 & $12,4 \%$ \\
\hline & Pilot & 1 & $0,8 \%$ \\
\hline
\end{tabular}

Sumber: Hasil Olahan Data (2020)

\section{Gambar 2. Model Hasil Uji Hipotesis}

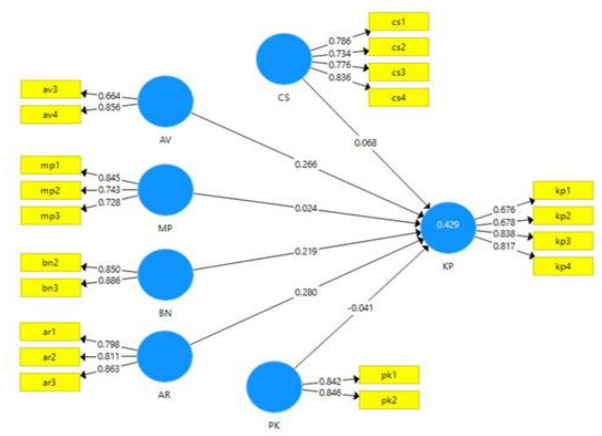

Sumber: Hasil Olahan Data (2020)

Faktor customer service $\left(\mathrm{X}_{1}\right)$ yang mencakup empat indikator mempunyai pengaruh total sebesar 0,068 terhadap keputusan pembelian (Y). Faktor availability of variety and junk food $\left(\mathrm{X}_{2}\right)$ yang mencakup dua variabel indikator mempunyai pengaruh total sebesar 0,266 terhadap keputusan pembelian (Y). Faktor maintenance of privacy $\left(\mathrm{X}_{3}\right)$ yang mencakup tiga indikator mempunyai pengaruh total sebesar 0,024 terhadap keputusan pembelian (Y). Faktor brand name $\left(\mathrm{X}_{4}\right)$ yang mencakup dua indikator mempunyai pengaruh total sebesar 0,219 terhadap keputusan pembelian (Y). Availability of ready-made food $\left(\mathrm{X}_{5}\right)$ yang mencakup tiga indikator mempunyai pengaruh total sebesar 0,280 terhadap keputusan pembelian (Y). Faktor protokol kesehatan $\left(\mathrm{X}_{6}\right)$ yang mencakup dua indikator mempunyai pengaruh total sebesar $-0,041$ terhadap keputusan pembelian (Y).

\section{Tabel 2. Hasil Construct Reliability dan} Validity

\begin{tabular}{lrr}
\hline & $\begin{array}{c}\text { Composite } \\
\text { reliability }\end{array}$ & $\begin{array}{c}\text { Average Variance } \\
\text { Extracted }\end{array}$ \\
\hline Customer Service
\end{tabular}

Sumber: Hasil Olahan Data (2020)

Uji Validitas

Berdasarkan data tabel 2 diatas hasil Average Variance Extracted (AVE) dari customer service adalah sebesar 0.615 , availability of variety and junk food sebesar 0.587, maintenance of privacy sebesar 0.599 , brand name sebesar 0.754 , dan availability of readymade food sebesar 0.680. Dapat dilihat bahwa seluruh nilai AVE pada setiap variabel $>0.50$, maka setiap variabel dinyatakan valid. Selain itu, hasil dari semua composite reliability di atas memiliki nilai $>0.070$.

Uji Reliabilitas

Hasil dari composite reliability customer service sebesar 0.859 , availability of variety and junk food sebesar 0.737, maintenance of privacy sebesar 0.817 , brand name sebesar 0.859 , dan availability of ready-made food sebesar 0.846. Hal tersebut membuktikan bahwa seluruh variabel memuaskan dan dapat digunakan untuk mengukur hubungan antar variabel. 


\section{Tabel 3. Hasil Model Pengeluaran}

\begin{tabular}{|c|c|}
\hline & Outer Loading \\
\hline \multicolumn{2}{|l|}{ Customer Senvice } \\
\hline CS1 Kebersihan ruangan restoran teriaga dengan baik & 0.786 \\
\hline CS2 Karyawan berperilaku baik saat melayani tamu & 0.734 \\
\hline CS3 Makannan dan minuman vang ada di menu selalu tersedia & 0.776 \\
\hline CS4 Lavout restoran tertata dengan rapih & 0.836 \\
\hline \multicolumn{2}{|l|}{ Availabilitv of Varien and Junk Food } \\
\hline AV3 Kualitas makanan baik & 0.664 \\
\hline AV4 Restoran memiliki garana vang memadahi & 0.856 \\
\hline \multicolumn{2}{|l|}{ Maintenance of Privacy } \\
\hline MP1 Konsumen merasa aman dan nvaman gaat makan di restoran & 0.845 \\
\hline MP2 Tidak memiliki antrian yang panjang & 0.743 \\
\hline NP3 Linghungan restoran bersih dan nvaman & 0.728 \\
\hline \multicolumn{2}{|l|}{ NP4 Lokasi restoran mudah untuk dijangkau } \\
\hline \multicolumn{2}{|l|}{ Brand Name } \\
\hline BN2 Uang yang dibayarkan untuk makanan sepadan dengan yang disajikan & 0.850 \\
\hline BN3 Harga makanan yang dijual terjangkau & 0.886 \\
\hline \multicolumn{2}{|l|}{ Availabilinv of Readis:Made Food } \\
\hline AR. Penvaiian makanan dilakukan dengan cepat & 0.798 \\
\hline AR2 Makanan yang disaikan reatoran tidak berbahava bagei kesehatan & 0.811 \\
\hline AR3 Memberikan pelayanan yang cepat saat melayani tamu & 0.863 \\
\hline \multicolumn{2}{|l|}{ Protokol Kesehatan } \\
\hline pK1 Kapasitas Makcimum restoran 50\% dari kapasitas normal & 0.842 \\
\hline PK2 Restoran mengikuti standar protokol (3M) & 0.846 \\
\hline \multicolumn{2}{|l|}{ Keputusan Pembelian } \\
\hline KP2 Sava mencari informasi dahulu sebelum melahuluan keputusan pembelian & 0.678 \\
\hline KP3 Sava melakukan pembelian setelah menentukan pilihan restoran & 0.838 \\
\hline KP4 Sava merasa puas setelah makan di rettoran vang gava pilih & 0.817 \\
\hline
\end{tabular}

Sumber: Hasil Olahan Data (2020)

Menurut Chin (1998) nilai outer loading antara 0,50 - 0,60 sudah dianggap cukup untuk memenuhi syarat convergent validity. Menurut hasil data tabel 3 diatas, nilai keseluruhan outler loading sudah diatas 0,60. Sehingga semua indikator variabel $\mathrm{X}$ dan $\mathrm{Y}$ dapat dikatakan valid.

\section{Hasil Discriminant Validity}

\section{Tabel 4. Hasil Evaluasi Validitas Diskriminan}

\begin{tabular}{|c|c|c|c|c|c|c|c|}
\hline & $\begin{array}{l}\text { Availability } \\
\text { of Ready- } \\
\text { made food }\end{array}$ & $\begin{array}{l}\text { Availability } \\
\text { of food } \\
\text { variety }\end{array}$ & $\begin{array}{l}\text { Brand } \\
\text { Name }\end{array}$ & $\begin{array}{l}\text { Customer } \\
\text { Service }\end{array}$ & $\begin{array}{l}\text { Keputusan } \\
\text { Pembelian }\end{array}$ & $\begin{array}{l}\text { Maintenance } \\
\text { of Privacy }\end{array}$ & $\begin{array}{c}\text { Protolkol } \\
\text { Kesehatarat }\end{array}$ \\
\hline $\begin{array}{l}\text { Availability } \\
\text { of Ready- } \\
\text { made food }\end{array}$ & 0.825 & & & & & & \\
\hline $\begin{array}{l}\text { Avalabalilty } \\
\text { of food } \\
\text { variety }\end{array}$ & 0.407 & 0.765 & & & & & \\
\hline Brand Name & 0.564 & 0.404 & 0.868 & & & & \\
\hline $\begin{array}{l}\text { Customer } \\
\text { Service }\end{array}$ & 0.588 & 0.651 & 0.417 & 0.784 & & & \\
\hline $\begin{array}{l}\text { Keputusan } \\
\text { Pembelian }\end{array}$ & 0.547 & 0.507 & 0.507 & 0.493 & 0.756 & & \\
\hline $\begin{array}{l}\text { Maintenance } \\
\text { of Privacy }\end{array}$ & 0.718 & 0.566 & 0.580 & 0.768 & 0.527 & 0.774 & \\
\hline $\begin{array}{l}\text { Protokol } \\
\text { Kesehatan }\end{array}$ & 0.528 & 0.467 & 0.486 & 0.549 & 0.391 & 0.674 & 0.844 \\
\hline
\end{tabular}

Sumber: Hasil Olahan Data (2020)

Menurut hasil dari data tabel 4 diatas, outer loading indikator pada konstruk harus lebih tinggi daripada semua cross-loading dengan konstruk lainnya. Selain itu, square root dari AVE masing-masing konstruk harus lebih tinggi dari korelasi tertinggi dengan konstruk lainnya (Maddeppungeng \& Mangun Kusuma, 2019) (Fornell-Larcker criterion).

Tabel 5. Evaluasi Hasil R Square

\begin{tabular}{lr}
\hline & R Square \\
\hline Keputusan Pembelian & 0.429
\end{tabular}

Sumber: Hasil Olahan Data (2020)

Berdasarkan pada tabel 5 di atas, hasil nilai $\mathrm{R}^{2}$ keputusan pembelian adalah sebesar $42.9 \%$ sedangkan sisanya sebesar $57.1 \%$ dipengaruhi faktor lain yang tidak diteliti.

Tabel 6. Hasil Evaluasi Collinearity

\begin{tabular}{lc}
\hline \multicolumn{2}{c}{ Sebagai Prediktor Keputusan Pembelian } \\
\hline \multicolumn{1}{c}{ Konstruk } & VI F \\
\hline Availability of Ready-made food & 2,284 \\
\hline Availability of food variety & 1,868 \\
\hline Brand Name & 1,693 \\
\hline Customer Service & 2,914 \\
\hline Maintenance of Privacy & 4,082 \\
\hline Protokol Kesehatan & 1,944
\end{tabular}

Sumber: Hasil Olahan Data (2020)

Dapat dilihat dari hasil tabel 6, nilai VIF pada seluruh konstruk tidak lebih besar dari 10 (VIF < 10). Oleh karena itu, dapat disimpulkan bahwa tidak terjadi gejala multikolinearitas pada model regresi penelitian ini. 
Tabel 7. Hasil Uji Hipotesis

\begin{tabular}{|c|c|c|c|}
\hline Hipotesis & $\begin{array}{c}\text { Koefisien } \\
\text { jalur }\end{array}$ & T Hitung & Hasil \\
\hline $\begin{array}{l}\text { Faktor customer service } \\
\text { memengaruhi keputusan pembelian } \\
\text { konsumen generasi } Z \text { pada restoran } \\
\text { di Kelapa Gading }\end{array}$ & 0,672 & 0,424 & $\begin{array}{c}\text { Tidak } \\
\text { mendukung }\end{array}$ \\
\hline $\begin{array}{l}\text { Faktor availability of variety and } \\
\text { junk food memengaruhi keputusan } \\
\text { pembelian konsumen generasi } Z \\
\text { pada restoran di Kelapa Gading }\end{array}$ & 0,011 & 2,537 & Mendukung \\
\hline $\begin{array}{l}\text { Faktor maintenance of privacy } \\
\text { memengaruhi keputusan pembelian } \\
\text { konsumen generasi } Z \text { pada restoran } \\
\text { di Kelapa Gading }\end{array}$ & 0,904 & 0,121 & $\begin{array}{c}\text { Tidak } \\
\text { mendukung }\end{array}$ \\
\hline $\begin{array}{l}\text { Faktor brand name memengaruhi } \\
\text { keputusan pembelian konsumen } \\
\text { generasi } Z \text { pada restoran di Kelapa } \\
\text { Gading }\end{array}$ & 0,041 & 2,044 & Mendukung \\
\hline $\begin{array}{l}\text { Faktor availability of ready-made } \\
\text { food memengaruhi keputusan } \\
\text { pembelian konsumen generasi } Z \\
\text { pada restoran di Kelapa Gading }\end{array}$ & 0,014 & 2,423 & Mendukung \\
\hline $\begin{array}{l}\text { Faktor protokol Kesehatan } \\
\text { memengaruhi keputusan pembelian } \\
\text { konsumen generasi } Z \text { pada restoran } \\
\text { di Kelapa Gading }\end{array}$ & 0,770 & 0,292 & $\begin{array}{c}\text { Tidak } \\
\text { mendukung }\end{array}$ \\
\hline
\end{tabular}

Sumber: Hasil Olahan Data (2020)

\section{Pembahasan}

Hasil yang didapat dari dari penelitian ini: 1 . $\mathrm{H}_{0}$ gagal ditolak sehingga $\mathrm{H}_{1}$ tidak dapat diterima. Hasil dari penelitian ini membuktikan bahwa tidak ada pengaruh yang signifikan antara pengaruh customer service dengan keputusan pembelian konsumen generasi $\mathrm{Z}$.

Hasil dari penelitian ini sejalan dengan penelitian yang telah dilakukan oleh Saputra, Soewarno dan Isnalita (2017). Pada penelitian tersebut, dinyatakan bahwa tingkat layanan memiliki pengaruh yang sangat kecil terhadap keputusan pembelian konsumen karena tingkat layanan bukanlah faktor paling utama yang diperhatikan saat melakukan pembelian oleh generasi $\mathrm{Z}$.

2. $\mathrm{H}_{0}$ ditolak sehingga $\mathrm{H}_{2}$ dapat diterima.

Hasil dari penelitian ini membuktikan bahwa terdapat pengaruh yang signifikan antara pengaruh availability of variety and junk food dengan keputusan pembelian konsumen generasi Z. Maka simpulan dari hasil tersebut adalah konsumen generasi $\mathrm{Z}$ akan lebih tertarik dengan restoran yang menyediakan berbagai macam variasi makanan dan tersedia makanan junk food.

3. $\mathrm{H}_{0}$ gagal ditolak sehingga $\mathrm{H}_{3}$ tidak dapat diterima. Hal ini membuktikan bahwa tidak terdapat pengaruh yang signifikan antara pengaruh maintenance of privacy dengan keputusan pembelian konsumen generasi $Z$. Generasi $Z$ dikenal dengan generasi yang suka untuk bersosialiasi dan berinteraksi dengan sesama. Oleh karena itu, keramaian dalam restoran tidak akan menjadi suatu faktor yang mengganggu saat makan di restoran.

4. $\mathrm{H}_{0}$ ditolak sehingga $\mathrm{H}_{4}$ dapat diterima.

Simpulan dari penelitian ini membuktikan bahwa terdapat pengaruh yang signifikan antara pengaruh brand name dengan keputusan pembelian konsumen generasi Z. Apabila restoran tersebut terkenal, maka konsumen generasi $Z$ akan lebih tertarik untuk datang dan makan di restoran tersebut, dan sebaliknya.

5. $\mathrm{H}_{0}$ ditolak sehingga $\mathrm{H}_{5}$ dapat diterima. Penelitian ini membuktikan bahwa terdapat pengaruh yang signifikan antara pengaruh availability of ready-made food dengan keputusan pembelian konsumen generasi $\mathrm{Z}$ di restoran wilayah Kelapa Gading. Apabila restoran tersebut menyajikan makanan dengan cepat, maka konsumen generasi $\mathrm{Z}$ lebih tertarik dan merasa puas saat mengunjungi restoran tersebut.

6. $\mathrm{H}_{0}$ gagal ditolak sehingga $\mathrm{H}_{6}$ tidak dapat diterima. Hasil dari penelitian ini membuktikan bahwa tidak adanya pengaruh yang signifikan antara pengaruh protokol kesehatan dengan keputusan pembelian konsumen generasi Z. Hasil penelitian ini didukung dengan pernyataan dari hasil survei BPS (Badan Pusat Statistik), hasil survei tersebut menyatakan bahwa generasi $\mathrm{Z}$ merupakan generasi tersulit untuk mengikuti protokol kesehatan dalam pencegahan COVID-19.

\section{Simpulan}

Dalam penelitian ini, terdapat 6 faktor yang memengaruhi keputusan pembelian konsumen generasi $\mathrm{Z}$ di restoran wilayah Kelapa Gading. Faktor-faktor tersebut adalah customer service, availability of variety and junk food, maintenance of privacy, brand name, availability of ready-made food dan protokol kesehatan. Seluruh faktor ini sudah ditetapkan sebagai faktor yang valid setelah diuji dengan PLS.

Hasil dari penelitian yang dilakukan ini juga membuktikan bahwa faktor customer service bukan menjadi faktor utama yang 
memengaruhi keputusan pembelian konsumen generasi $\mathrm{Z}$ di restoran wilayah Kelapa Gading. Faktor availability of variety and junk food merupakan faktor yang sangat diperhatikan oleh konsumen generasi Z dalam mengambil keputusan untuk membeli suatu produk makanan atau minuman di restoran wilayah Kelapa Gading. Maintenance of privacy ternyata bukanlah hal yang menjadi faktor utama yang dapat memengaruhi keputusan pembelian konsumen generasi $\mathrm{Z}$ di restoran wilayah Kelapa Gading. Ternyata brand name menjadi salah satu faktor yang diperhatikan oleh konsumen generasi Z, karena adanya nama restoran dengan citra yang baik akan selalu diingat dan dapat meningkatkan kepuasan dari konsumen, khususnya generasi $\mathrm{Z}$ yang ingin makan di restoran wilayah Kelapa Gading. Selanjutnya, availability of ready-made food menjadi salah satu faktor yang sangat diperhatikan oleh konsumen generasi $\mathrm{Z}$ karena penyajian makanan yang cepat saat makan di restoran membuat konsumen generasi $\mathrm{Z}$ lebih puas. Sedangkan pada faktor protokol kesehatan tidak dinilai menjadi salah satu faktor utama yang memengaruhi keputusan pembelian konsumen generasi $\mathrm{Z}$ dalam memilih restoran di wilayah Kelapa Gading. Protokol Kesehatan sangat sulit untuk ditaati para konsumen generasi $\mathrm{Z}$, hal tersebut kemungkinan disebabkan karena banyaknya generasi $\mathrm{Z}$ yang berpikir bahwa mereka tidak mudah untuk terserang virus COVID-19.

Penelitian ini menekankan bahwa dari keenam faktor yang diteliti, tidak semua faktor memiliki pengaruh yang besar untuk memengaruhi keputusan pembelian konsumen generasi $\mathrm{Z}$ di restoran wilayah Kelapa Gading. Faktor availability of variety and junk food, availability of ready-made food dan brand name sangat lebih diperhatikan oleh konsumen generasi Z, oleh karena itu pemilik restoran memiliki tugas yang penting untuk dapat merancang strategi dan menyajikan makanan dengan lebih cepat dan terus meningkatkan citra restoran mereka agar memiliki nama yang baik di mata konsumen, khususnya konsumen generasi $\mathrm{Z}$. Selain daripada itu, faktor customer service, maintenance of privacy, dan protokol kesehatan bukanlah menjadi faktor utama yang memengaruhi keputusan pembelian konsumen generasi $\mathrm{Z}$ di restoran wilayah Kelapa Gading. Walaupun bukan menjadi faktor yang utama, namun pemilik restoran juga tetap harus memberikan layanan yang baik dan tetap mematuhi peraturan protokol kesehatan yang sudah di tetapkan agar konsumen pada umumnya tetap merasa nyaman dan semakin puas saat makan di restoran tersebut.

Keterbatasan penelitian ini antara lain adalah kecilnya ruang lingkup yang diteliti dan tidak semua faktor-faktor yang dapat memengaruhi keputusan pembelian konsumen generasi $\mathrm{Z}$ telah digunakan. Diharapkan, penelitian selanjutnya dapat menggunakan variablevariabel lain yang tidak dicantumkan pada penelitian ini, seperti pengaruh promosi dan media sosial pada keputusan pembelian generasi Z. Penelitian selanjutnya juga diharapkan dapat menggunakan segmen konsumen yang berbeda atau memperluas wilayah geografi dalam pengambilan sampel. Dengan sampel yang lebih luas diharapakan dapat berkontribusi lebih baik untuk pengembangan lebih lanjut lagi dari faktorfaktor diatas.

\section{Daftar Pustaka}

Abdullah, T. (2017). Customer Motivation of Restaurant in Bandung When Eating Outside of the Home. Tourism Scientific Journal, 2, 192-212.

Aditama, A. P. (2011). Jogja Resto dan Galeri, Restoran dan Galeri Seni Lukis di Yogyakarta. Skripsi Universitas Atma Jaya Yogyakarta. Yogyakarta.

Agustina, I. K. E. (2018). Memahami Generasi Z Lebih Dekat.

Akbar, M. (2016). Pengaruh Kualitas Pelayanan Terhadap Kepuasan Pelanggan (Studi Pada Pengunjung Wisata Kampoeng Kidz Kota Batu). 119.

Asmara, A. Y. (2020). ANALISIS FAKTOR PERTIMBANGAN GENERASI Z DALAM MEMILIH RESTORAN DI KOTA BANDUNG Universitas Pendidikan Indonesia repository.upi.edu perpustakaan.upi.edu. 1-7.

Astika, Gumilang, D. A., \& Kurniasih, A. (2017). ANALISIS PENGARUH HARGA, KUALITAS PRODUK DAN KULITAS PELAYANAN TERHADAP KEPUASAN KONSUMEN MELALUI KEPUTUSAN PEMBELIAN PADA GALERI INDONESIA WOW LLP KUKM DI JAKARTA. VII(1), 76-88. 
Fitriatun, E. (2019). Pengaruh Marketing Mix Terhadap Keputusan Pembelian. Journal of Chemical Information and Modeling, 53(9), 1689-1699.

Gariswasita, A. (2013). Pengaruh Store Atmosphere Terhadap Keputusan Pembelian ( Studi Pada Five Points Coffee and Chocolate Semarang ).

Ghanimata, F. (2012). Analisis Pengaruh Harga, Kualitas Produk, dan Lokasi Terhadap Keputusan Pembelian.

Hanaysha, J. (2016). Testing the Effects of Food Quality, Price Fairness, and Physical Environment on Customer Satisfaction in Fast Food Restaurant Industry. May. https://doi.org/10.18488/journal.1006/2 016.6.2/1006.2.31.40

Hwang, J., Yoon, S.-Y., \& Bendle, L. J. (2011). Desired privacy and the impact of crowding on customer emotions and approach-avoidance responses. 224250.

https://doi.org/10.1108/0959611121120 6150

Irwanto, I., \& Hariatiningsih, L. R. (2019). Aktivitas Santap dan Minum Generasi Z pada Media Sosial Instagram. Mediator: Jurnal Komunikasi, 12(2). https://doi.org/10.29313/mediator.v12i2 .5048

Islam, N., Mustafi, M. A. A., Ahmed, S., Rashid, M., Kabir, A. U., \& Nazrul, T. (2018). Factors influencing the selection of restaurant for dining in Dhaka City of Bangladesh. DAV Research Journal, 3(1), $1-12$. https://www.journalofbusiness.org/inde x.php/GJMBR/article/view/2552

Jin, N. P., Lee, S., \& Huffman, L. (2012). Impact of Restaurant Experience on Brand Image and Customer Loyalty: Moderating Role of Dining Motivation IMPACT OF RESTAURANT EXPERIENCE ON BRAND IMAGE AND CUSTOMER LOYALTY: 8408. https://doi.org/10.1080/10548408.2012. 701552

Kemenkes. $2020.2 \quad$ Nomor HK.01.07/MENKES/382/2020 tentang Protokol Kesehatan bagi Masyarakat di Tempat dan Fasilitas Umum dalam Rangka Pencegahan dan Pengendalian Corona Virus Disease 2019 (COVID19). Jakarta.

Krisdianti, D. L., \& Sunarti. (2019). Pengaruh kualitas pelayanan terhadap kepuasan konsumen pada restoran pizza hut malang town square. 70(1), 36-44.

Kusumawaty, A. (2012). APLIKASI PEMESANAN MAKANAN PADA RESTORAN BERBASIS ANDROID DAN PHP MENGGUNAKAN PROTOKOL JSON.

Lee, H., \& Kim, W. G. (2012). physical environment, food, and service on restaurant image, customer perceived value, customer satisfaction, and behavioral intentions. https://doi.org/10.1108/0959611121120 6141

Maddeppungeng, A., \& Mangun Kusuma, W (2019). Pengaruh Strategi Dan Praktik Supply Chain Management Terhadap Kinerja Operasional Perusahaan. Jurnal Fondasi, 8(2), 97-108.

Mahardika, B. R. (2018). Mengenal Industri Makanan dan Minuman di Era Industri 4.0. M. Bangun, Reza, Ed.)(1st Ed.). Yogyakarta: Forbil Intitute.

Mandasari, V., \& Tama, B. A. (2011). Analisis Kepuasan Konsumen Terhadap Restoran Cepat Saji Melalui Pendekatan Data Mining : Studi Kasus XYZ. 6(1), 4-7.

Marlinus, D. (2017). keputusan pembelian berdasarkan faktor psikologis dan bauran pemasaran PT.Intercom Mobilindo Padang. 01(01), 57-66.

Mirhadyan, L., Latreyi, S. M., Kazem, E., \& Leili, N. (2019). Junk Food Consumption and its Associated Factors in High School Students in Rasht in 2017. 17(1).

Nirwaty, T., \& Agave, N. S. (2020). PELAKSANAAN PROSEDUR PROTOKOLER COVID-19 DALAM MELAYANI TAMU DISUSHI TEI RESTORAN DI MEDAN SUMATERA UTARA. 2.

Olsen, N. V., Menichelli, E., Sørheim, O., \& Næs, T. (2012). Likelihood of buying healthy convenience food: An at-home testing procedure for ready-to-heat meals. Food Quality and Preference, 24(1), 171-178. https://doi.org/10.1016/j.foodqual.2011. 11.001

Rachmawati, R. (2011). Peranan Bauran Pemasaran (Marketing Mix) terhadap Peningkatan Penjualan (Sebuah Kajian terhadap Bisnis Restoran ). 2(2), 143- 
150.

Syahbani, M. F., \& Widodo, A. (2017). Food blogger instagram: Promotion through social media. Jurnal Ecodemica, 1(1), 46-58.

Tungkiman, R. F. (2016). Faktor-Faktor yang Menentukan Dining Choice Masyarakat Surabaya dalam Memilih Restoran. CALYPTRA, 4(2), 1-12.

Wahyuningsih, S. (2019). PENGARUH TENAGA TATA HIDANG PARIWISATA TERHADAP KUALITAS PELAYANAN DI HOTEL. 13(11), 1775-1782.

Waluya, A. I., \& Iqbal, M. A. (2019). How product quality, brand image, and customer satisfaction affect the purchase decisions of Indonesian automotive customers Rhian Indradewa *. 10(2), 177-193.

Wheeler, K. (2017). The moral economy of ready-made food. https://doi.org/10.1111/14684446.12333 